\title{
Stem Cell Therapy for Neurogenic Bladder Dysfunction in Rodent Models: A Systematic Review
}

\author{
Hanieh Salehi-Pourmehr', Sakineh Hajebrahimi ${ }^{1,2}$, Reza Rahbarghazi ${ }^{3}$, Fariba Pashazadeh ${ }^{1}$, Javad Mahmoudi ${ }^{4}$, \\ Narjes Maasoumi ${ }^{5}$, Saeed Sadigh-Eteghad ${ }^{4,6,7}$ \\ ${ }^{1}$ Research Center for Evidence-Based Medicine, Iranian EBM Centre: A Joanna Briggs Institute (JBI) Center of Excellence, Tabriz University of Medical \\ Sciences, Tabriz, Iran \\ ${ }^{2}$ Urology Department, Faculty of Medicine, Tabriz University of Medical Sciences, Tabriz, Iran \\ ${ }^{3}$ Stem Cell Research Center, Tabriz University of Medical Sciences, Tabriz, Iran \\ ${ }^{4}$ Neurosciences Research Center, Tabriz University of Medical Sciences, Tabriz, Iran \\ ${ }^{5}$ University Hospital Southampton, Southampton, United Kingdom \\ ${ }^{6}$ East-Azerbaijan Comprehensive Stroke Program, Tabriz University of Medical Sciences, Tabriz, Iran \\ ${ }^{7}$ Department of Persian Medicine, Faculty of Persian Medicine, Tabriz University of Medical Sciences, Tabriz, Iran
}

Purpose: Neurogenic bladder dysfunction (NGB) has an impact on the quality of life, which made it an important research subject in preclinical studies. The present review investigates the effect of stem cell (SC) therapy on bladder functional recovery after the onset of spinal cord injury (SCI), multiple sclerosis (MS), Parkinson disease (PD), and stroke in rodent models. Methods: All experiments evaluated the regenerative potential of SC on the management of NGB in rodent models up to June 2019, were included. From 1,189 relevant publications, 20 studies met our inclusion criteria of which 15 were conducted on SCI, 2 on PD, 2 on stroke, and 1 on MS in the rodent models. We conducted a meta-analysis on SCI experiments and for other neurological diseases, detailed urodynamic findings were reported.

Results: The common SC sources used for therapeutical purposes were neural progenitor cells, bone marrow mesenchymal SCs, human amniotic fluid SCs, and human umbilical cord blood SCs. There was a significant improvement of micturition pressure in both contusion and transaction SCI models 4 and 8 weeks post-SC transplantation. Residual urine volume, micturition volume, and bladder capacity were improved 28 days after SC transplantation only in the transaction model of SCI. Nonvoiding contraction recovered only in 56 days post-cell transplantation in the contusion model.

Conclusions: Partial bladder recovery has been evident after SC therapy in SCI models. Due to limitations in the number of studies in other neurological diseases, additional studies are necessary to confirm the detailed mechanism for bladder recovery.

Keywords: Stem cell therapy; Neurogenic bladder; Rodent models; Systematic review

- Fund/Grant Support: This study was financially supported by Research center for Evidence-Based Medicine Tabriz University of Medical Sciences (grant No. 59224).

- Research Ethics: This meta-analysis was approved by the local ethical committee of Tabriz University of Medical Sciences (IR.TBZMED.

REC.1397.451).

- Conflict of Interest: No potential conflict of interest relevant to this article was reported.

Corresponding author: Saeed Sadigh-Eteghad (iD https://orcid.org/0000-00032872-1072

Neurosciences Research Center (NSRC), Tabriz University of Medical Sciences, 5166614756, Tabriz, Iran

E-mail: Saeed.sadigetegad@gmail.com

Submitted: February 14, 2020 / Accepted after revision: March 23, 2020 


\section{INTRODUCTION}

Neurogenic bladder (NGB) is an ineffective bladder that originated from the damage to the central or peripheral nervous system. Regarding the site and severity of injury to the nervous system, patients usually experience urinary frequency, incontinence, urgency, and urinary tract infection [1]. In the United States, a fraction of patients with multiple sclerosis (MS; $40 \%-$ 90\%), Parkinson disease (PD; 37\%-72\%), and stroke (15\%) suffer from NGB. In the $50 \%-90 \%$ of patients with MS, hyperreflexia is indicated and the others have areflexia [2]. After spinal cord injury (SCI), $70 \%-84 \%$ of patients confront with some degree of bladder dysfunction [3]. NGB has a tremendous effect on the quality of life [4]. In addition to physical and clinical aspects, the signs associated with urinary incontinence can negatively impact a patient's quality of life [5]. Different strategies including conservative methods (lifestyle changes, bladder retraining, pelvic floor muscle training), pharmacological (anticholinergics, $\beta$-adrenoceptor agonists) and nonpharmacological approaches (electrical stimulation, clean intermittent catheterization, and indwelling catheters), as well as surgical interventions (augmentation cystoplasty), have been developed for the management of NGB. However, improvement in voiding dysfunction is not been fully achieved and also was accompanied by several side effects $[4,6-10]$. Based on the results from previous experiments, stem cell (SC) transplantation is used in the management of neuro-urological diseases accompanied by promising outcomes [11]. The potential of self-renewal, multilineage differentiation, site-specific migration, tissue regeneration, made SC as a beneficial therapeutic target in the treatment of several types of complications such as degenerative diseases [12]. The major issues in SC therapy correlate with cell survival, dynamic growth, and regeneration potential of transplanted cells in the long-term outcome [13]. Despite the promising effects of SC therapies, there is a concern about cellular rejection by the adaptive immune response in the host tissues. A large number of transplant cells die in the early hours to days postadministration [14]. Animal models are valuable tools for evaluating new therapeutic agents and efficacy of candidate interventions such as SC. Also, rodent models mimic many features of disorders and have been extensively applied to study the mechanisms of therapeutic interventions and assess the possible adverse effects of treatments [15]. Considering the possible unwanted effects associated with SC administration, appropriate integration to the host tissues, and a number of viable SCs, it limits the efficacy and therapeutic potential of this approach [16]. Despite these challenges, SC therapy makes significant steps toward the clinic in the coming decades [17]. Although several experimental types of research have been conducted to examine the potency of SCs on the management of bladder dysfunction, there is no general agreement on regenerative outcomes in empirical studies $[18,19]$. In the current systematic review, we highlighted the restoration of bladder function postSC transplantation in preclinical NGB dysfunction studies using meta-analysis on SCI and with a comprehensive systematic review in $\mathrm{PD}$, stroke, and MS.

\section{MATERIALS AND METHODS}

\section{Search Strategy}

A systematic search was conducted in Embase, ProQuest, Cochrane library, Clinicaltrial.gov, WHO, Google Scholar, MEDLINE via PubMed, Ovid, Scopus, Web of Science, ongoing trials registers, and conference proceedings in June 2019 with no limit of date or language. The list of included review articles, experiments, and contacted authors of included trials were screened for subsequent analyses. We also monitored the abstracts from international congress. Unpublished or incomplete experiments were scoped via researchers known to participate in similar studies.

\section{Inclusion and Exclusion Criteria}

All preclinical studies about NGB and SC transplantation as therapy on rodents (e.g., mouse and rat) models of SCI, PD, MS, and stroke were included. We excluded all studies reporting the effect of SC therapy associated with conditions other than the mentioned neurological disease models or with human subjects or in vitro studies without any access to full-text. Inclusion and exclusion criteria are summarized in Table 1. Title and abstract screening process were performed independently by 2 investigators. Then, each author separately evaluated the full-text of selected articles. Any dispute among different study sections between reviewers was resolved by debate until unanimity was reached. A preliminary review of the data was done on the identified citations in study selection I. Due to the profound heterogeneity within the data from various studies, a wide range of point estimates was achieved and thereby a second study selection was done (study selection II) to screen most relevant results for further statistical analysis. All types of SCs or other progenitor cells were included in the current systemat- 
Table 1. Inclusion and exclusion criteria in study selection rounds I and II

\begin{tabular}{|c|c|c|}
\hline Study selection & Inclusion criteria & Exclusion criteria \\
\hline \multirow[t]{3}{*}{ Round I } & Preclinical studies & In vitro studies \\
\hline & Studies on rodent models & Studies with human subjects \\
\hline & $\begin{array}{l}\text { Studies evaluating the effect of SCs therapy in the management of } \\
\text { neurogenic bladder following SCI, MS, PD, and stroke models }\end{array}$ & $\begin{array}{l}\text { Studies reporting the effect of SCs therapy associated with } \\
\text { conditions other than the mentioned neurological disease model }\end{array}$ \\
\hline \multirow[t]{2}{*}{ Round II } & Studies reporting data from the urodynamic study & Studies without any urodynamic data \\
\hline & & Studies involved combined treatment with SCs \\
\hline
\end{tabular}

SC, stem cell; PD, Parkinson disease; SCI, spinal cord injury; MS, multiple sclerosis.

ic review. Of note, autologous or human-derived bone marrow mesenchymal SCs (hBMSC), human amniotic fluid SC (hAFSC) and human umbilical cord blood SC (hUCMSC), oral mucosa, human embryonic SCs-medial ganglionic eminence (hESC-MGEs), human glial-restricted progenitors, immortalized neural SCs, neural-restricted progenitors (NRPs), glial-restricted progenitors (GRPs), human glial-restricted progenitors (hGRP) and astrocytes derived from hGRP, human-derived adipocyte SC, and interstitial cells of Cajal were enrolled in this study. The primary outcome measures were urodynamic-associated findings such as micturition pressure, residual urine volume, nonvoiding contraction, bladder capacity, micturition volume, maximum pressure, and detrusor hyperreflexia.

\section{Data Extraction}

Two authors independently recorded the information by using a data extraction form as follows: Author, year of publication and type, animal characteristics (including strain, species, and sex) and the model of neurological disease to induce NGB details, the characteristics of SCs (including type, route, time, dose, and frequency of transplantation), study quality evaluation, and the reporting of measures to reduce the risk of bias (see the following sections). We collected data for the nature of the outcome reported (urodynamic parameters), and animal number per group, mean outcome and standard deviation (SD) or standard error of the mean. In a single publication where various experiments were represented, the data were considered as independent experiments. Disagreement resolved in consultation with the third person. For graphically presented data, we monitored the values from graphs using Universal Desktop Ruler (ver. 2.9) or contacted the authors of the manuscript for the details.

\section{Methodological Quality of Studies}

For this propose, 2 reviewers assessed the methodological quality of the selected trials. The assessment of the risk of bias was done through a 6-criterion appraisal checklist containing sequence generation, allocation concealment, blinding, incomplete outcome data, and selective outcome reporting and other bias. The internal validity of the enrolled studies (e.g., selection, performance, detection, and attrition bias) and other study quality measures (e.g., reporting quality, power) were assessed using a modified version of the Collaborative Approach to Meta-Analysis and Review of Animal Data from Experimental Studies (CAMARADES) quality checklist [15].

\section{Statistical Analysis}

The outcomes of interest in the current analysis were the micturition pressure, micturition volume, maximum pressure, residual urine volume, nonvoiding contraction, or detrusor hyperreflexia in rodents with NGB induced by SCI. Results for PD, stroke, and MS were not subjected to the statistical analysis due to the lack of sufficient data. Meta-analysis of the data such as findings of urodynamic studies was done by using the MantelHaenszel method with Comprehensive Meta-Analysis software (ver. 2.2; Biostat, Englewood, NJ, USA). All variables were continuous data. Mean \pm SD was used to calculate the standardized mean difference and 95\% confidence interval (CI). Statistical heterogeneity was analyzed using the $\mathrm{I}^{2}$ value and the result of the chi-square test. A $\mathrm{P}<0.05$ and $\mathrm{I}^{2}>50 \%$ were considered suggestive of statistical heterogeneity. We used the fixed model for low heterogeneity and mixed model for high heterogeneity in parameter analysis. Subgroup analysis was done whenever it was possible. Results of the comprehensive meta-analysis to examine any potential publication bias in the studies are shown as Funnel plots. 


\section{RESULTS}

\section{Description of Studies}

We found 1,189 relevant publications during the searching of electronic databases. Among them, 1,281 were excluded after an intensive screening of the titles and abstracts, duplicate publications, or human subjects. The full-text of 53 articles was evaluated and finally, 19 studies met our inclusion criteria that evaluated SC therapy effects on NGB (Table 2). Among the included studies, 15 publications were conducted on SCI (of these 3 were induced by transection model and others were contusion model), 2 on PD (6-hydroxydopamine administration into medial forebrain bundle region, 2 related to stroke and one correlated with MS rodent models. Most of the publications used rats and only 3 studies related to SCI and MS experiments used the mouse as a model. In 4 publications, male rats were examined while the others were conducted on female rats, and gender was not mentioned in 2 publications. The common SCs type used in the studies were neural progenitor cells (NPCs), BMSc, hAFSC, and hUCMSC. The common delivery routes for cell transplantation were intrathecal, intrabladder wall or intratail vein, substantia nigra, and medial forebrain bundle. In one of the SCI studies, urodynamic data were not in accordance with the other data thereby we didn't include it in the metaanalysis [20]. Finally, 11 studies met all inclusion criteria. In one study, the urodynamic assessment was done 6 months post-cell transplantation [21] and in another study, NPC was transplanted 13 weeks after contusion lesion [22]. Therefore, we did not include these studies to analyze and eventually, 9 studies were used. A flow chart for data selection is represented in Fig. 1. We did not perform a meta-analysis in the other models of NGB (i.e., PD, stroke, and MS) due to the lack of sufficient studies.

\section{Risk of Bias in the Included Studies}

In the current study, a modified CAMARADES quality checklist was used to assess the internal and external validity of the selected studies. The checklist contains details notably randomized allocation (model/sham groups), blinded induction of the model and assessment of outcomes, calculation of the sample size, compliance with existing animal welfare act, the disclosure of all relevant conflicts of interest, reporting of animal exclusions, and publication in peer-reviewed journals. All articles had been issued in peer-reviewed journals. Seven studies had disclosure statements for conflicts of interest. All papers except one stated compliance with the animal protection act. The pro- cedure of random assignment to the groups was seen in $25 \%$ of studies. All selected articles declared blinded induction of the animal model. No study existed to state the methodology of sample size calculation and only 6 studies illustrated both animal exclusion criteria and blind outcome assessment (Fig. 2).

\section{Urodynamic Findings Parkinson disease}

Campeau showed that the ipsilateral transplantation of rat BMSCs (rBMSCs) into substantia nigra improved urodynamic parameters in the PD model up to 42 days. However, it was shown that encapsulated BMSCs (ErBMSCs) exacerbated the urodynamic parameters on days 7 and 14 after cell transplantation without any improvement during 42 days. rBMSC-treated animals showed a lower threshold, intermicturition pressure spontaneous activity, and uninhibited contraction 42 days post-cell transplantation compared to the control animals. The administration of ErBMSCs to rats yielded lower threshold pressure after 28 days and lower spontaneous activity on day 42 than that in rats given vehicle only [23]. In the study of Soler et al. [24], cystometric parameters were changed in all groups, 3 and 7 days after cell transplantation compared to parallel-matched controls. Cystometric parameters including bladder capacity, micturition pressure, spontaneous activity, and threshold pressure were improved in rats received BMSC and hAFSC 14 days after cell administration. On day 14, hBM-MSC injected rats showed improvement in micturition volume, bladder capacity, micturition pressure, mean bladder pressure between 2 micturitions, spontaneous activity, compliance, and threshold pressure. Moreover, nonsignificant differences were found in the cystometric parameter among the groups after 28 days [24].

\section{Stroke}

According to the study of Liang et al. [25], pre- and postadministration of SCs via the tail vein in ischemic rats, returned cystometric variables nearly to levels found in sham-operated rats. All rats were subjected to bilateral ovariectomy 2 weeks prior to middle cerebral artery occlusion (MCAO) to create a hypoestrogenic menopausal state. Results from cystometric analysis noted that ischemic rats showed increased values in peak voiding pressure and residual urine volume 1, 3, and 7 days after the induction of MCAO, which further decreased after cell administration. Both intercontraction intervals and voided volumes were reduced post-MCAO while these values increased after cell transplantation on days 3 and 7. 


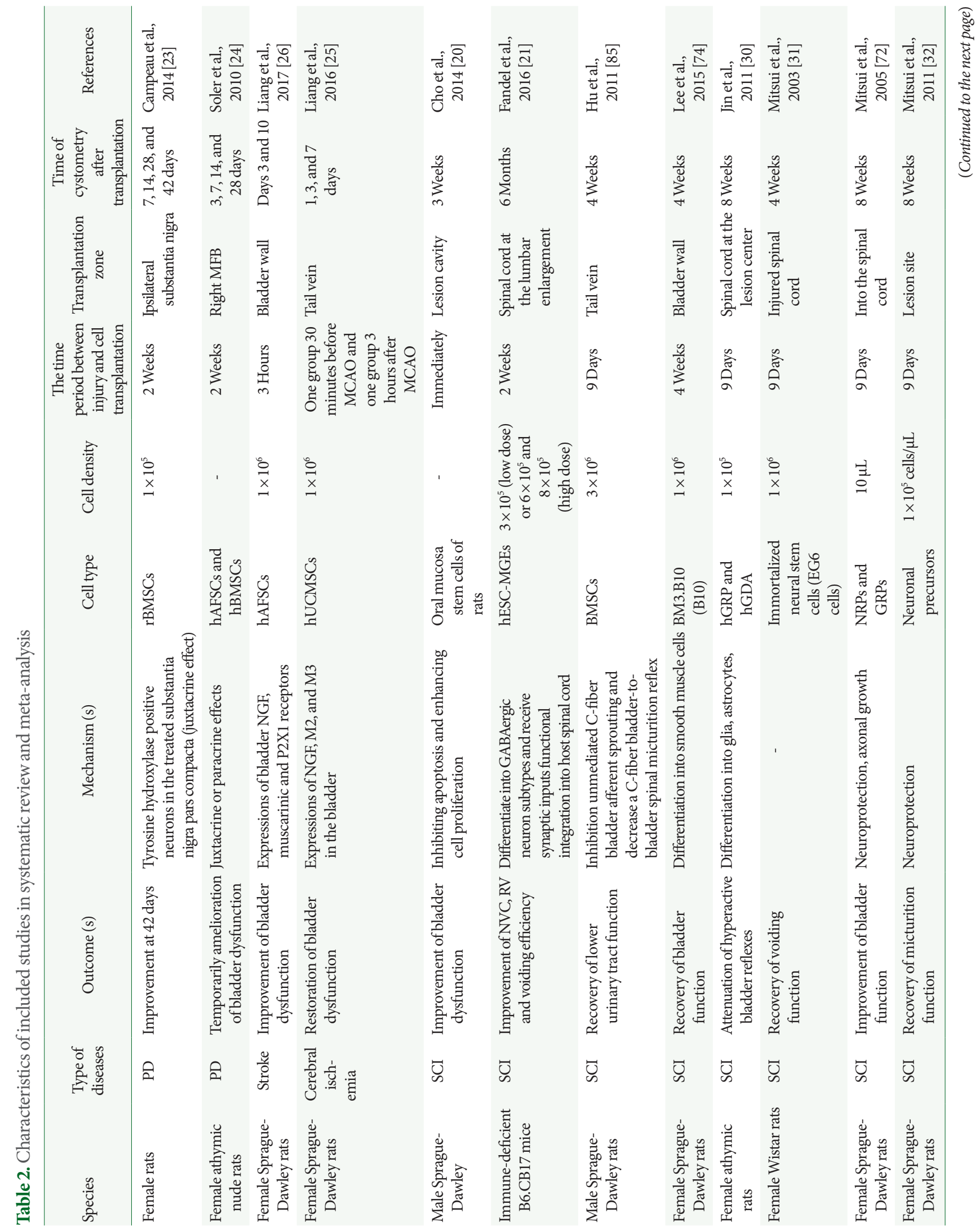




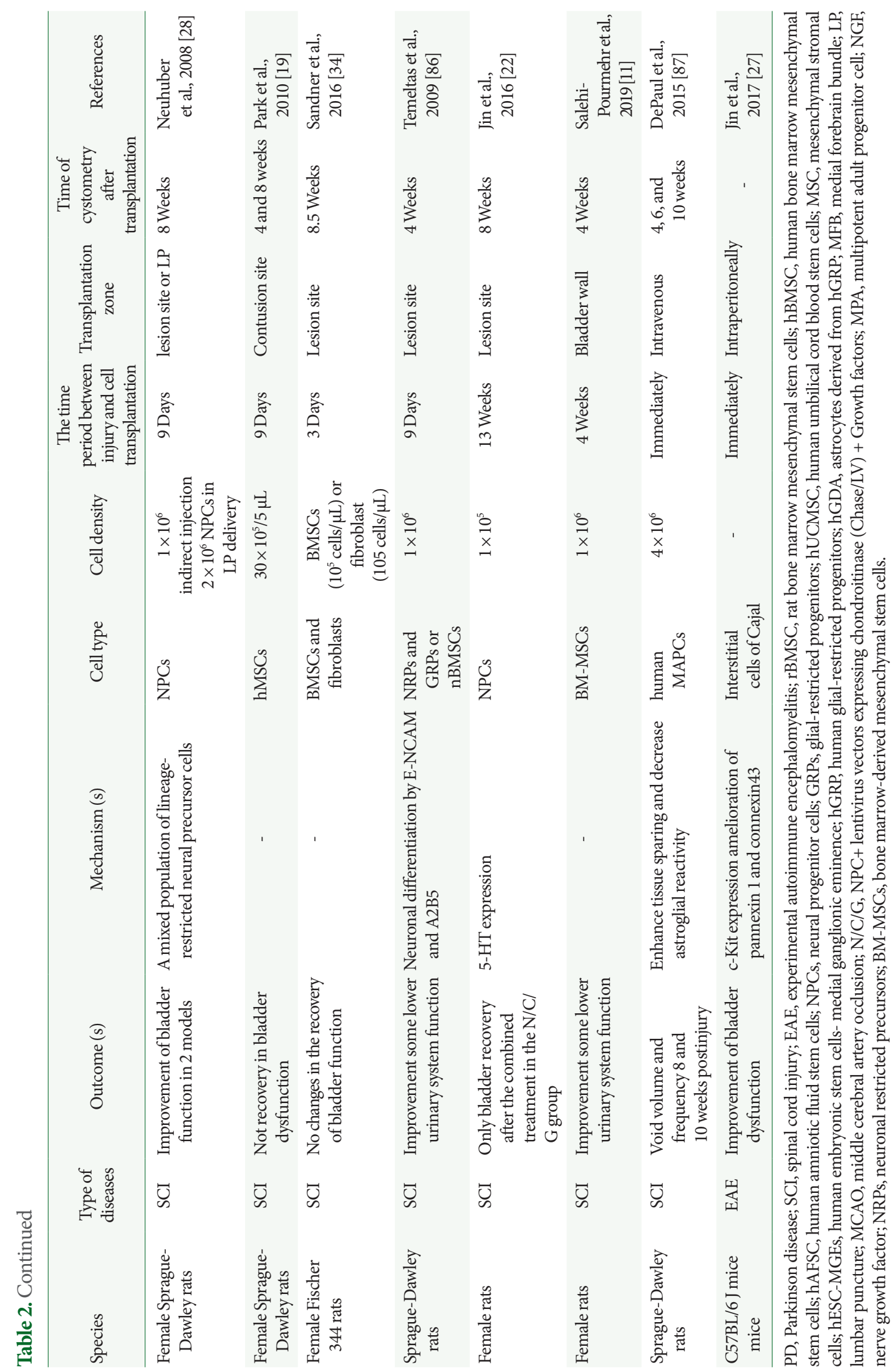


Liang et al. [25] stated that residual urine volume decreased significantly 10 days after treatment with the direct intrabladder transplantation of hAFSC compared to the sham and MCAO groups. Based on data, voided volume was increased 3 and 10
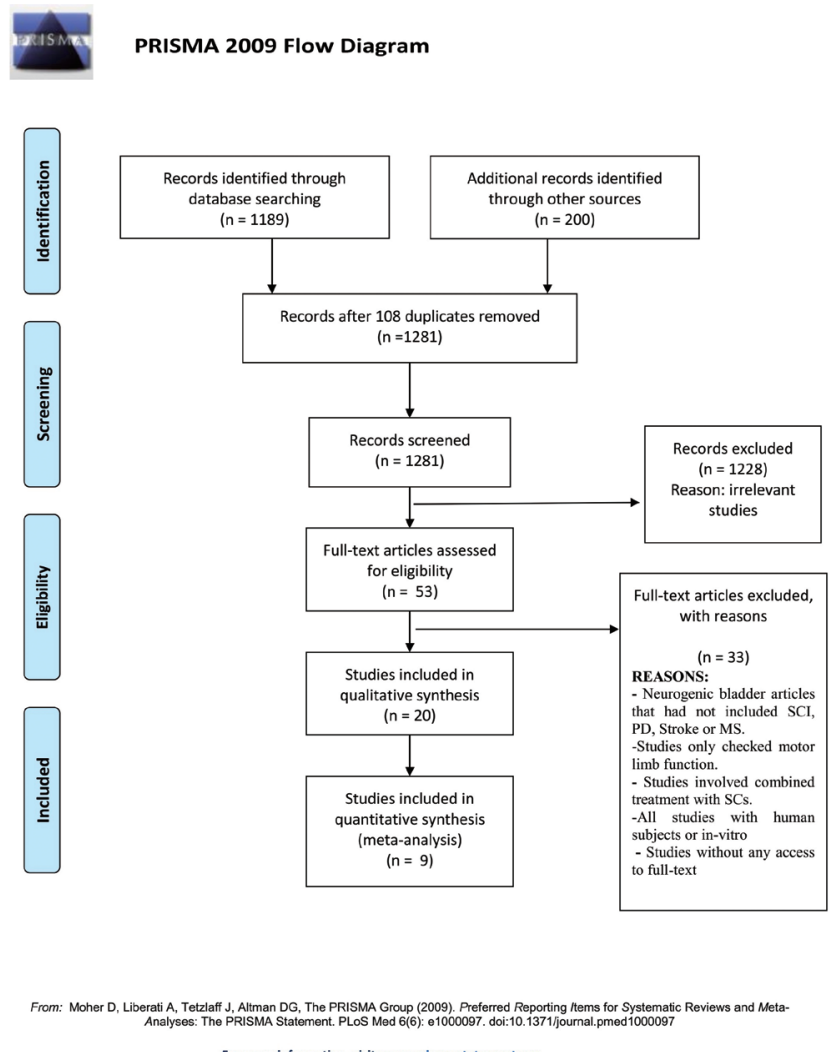

For more information, visit www. prisma-statement.org.

Fig. 1. Preferred Reporting Items for Systematic Reviews and Meta-Analyses (PRISMA) diagram of included studies in qualitative and quantitative stages. SCI, spinal cord injury; PD, Parkinson disease; MS, multiple sclerosis. days after the induction of MCAO in the hAFSC-treated group. Also, intercontraction intervals were increased 10 days after cell transplantation compared to the MCAO group [26].

\section{Multiple sclerosis}

We found only one study evaluated the impacts of intraperitoneal injection with interstitial Cajal cells on bladder function. Marked bladder dysfunction was developed in experimental autoimmune encephalomyelitis (EAE) mice indicated by urinary retention, the increase of micturition, and urine output reduction per micturition. In mice treated with SC factor, the diameter of the bladder was reduced compared to the EAE mice [27].

\section{Spinal cord injury}

Among the remained studies that met our inclusion criteria in 2 stages of study selection, we only included the studies in our meta-analysis in which the time (28- or 56-day post-SCI induction) and route of cell transplantation (lesion site) were homogenous.

\section{Micturition Pressure}

Of 10 trials, 6 experiments $(\mathrm{n}=155 ; 87$ treatments and 68 nontreated controls) presented data correlated with micturition pressure [28-33]. The standardized mean difference (SMD) change of micturition pressure improvement from baseline was $-1.093(95 \% \mathrm{CI},-1.42$ to -0.76$)(\mathrm{P}<0.001)$. Heterogeneity assay revealed $\mathrm{P}=0.116$ and $36.5 \%$ of Higgins' $\mathrm{I}^{2}$. In subgroup analysis, the SMD change of micturition pressure in the contusion model was $-1.002(95 \% \mathrm{CI},-1.36$ to -0.64$)(\mathrm{P}<0.001)$ and in the transection model was $-1.66(95 \% \mathrm{CI},-2.56$ to -0.76$)(\mathrm{P}<0.001)$

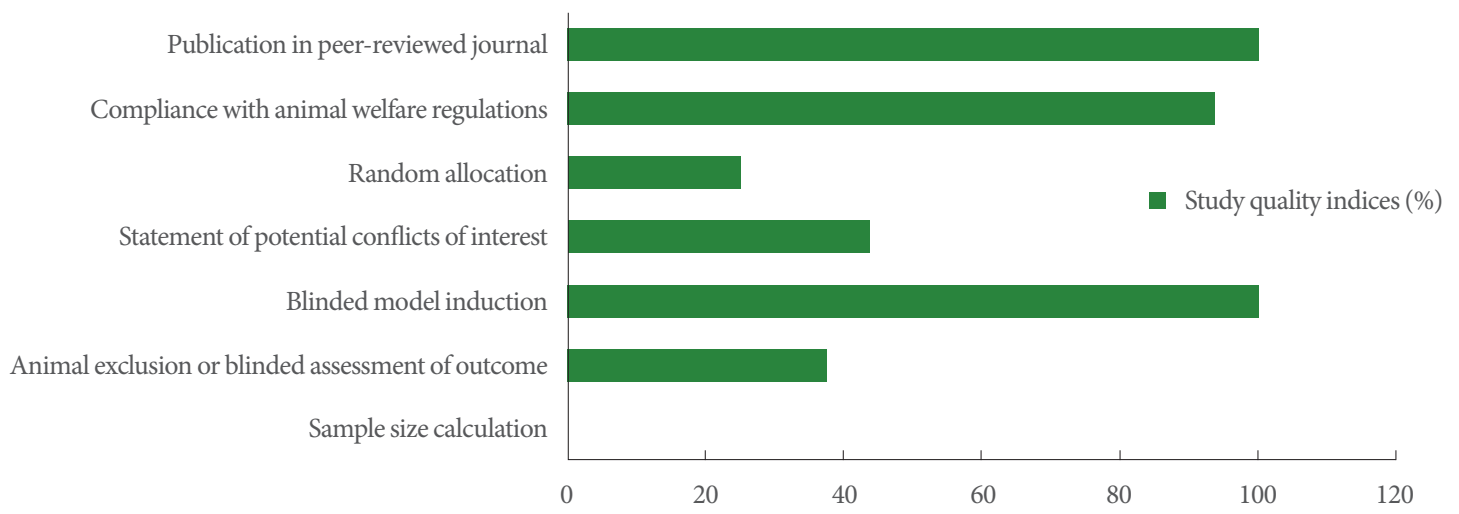

Fig. 2. Percentage of selected experiments for each item in the modified version of the CAMARADES (Collaborative Approach to Meta-Analysis and Review of Animal Data from Experimental Studies) quality checklist. 


\begin{tabular}{|c|c|c|c|c|c|c|c|c|}
\hline \multirow[t]{2}{*}{ Study name } & \multirow[t]{2}{*}{ Group by } & \multicolumn{7}{|c|}{ Statistics for each study } \\
\hline & & $\begin{array}{l}\text { Std diff } \\
\text { in means }\end{array}$ & $\begin{array}{l}\text { Stand ard } \\
\text { error }\end{array}$ & Variance & $\begin{array}{c}\text { Lower } \\
\text { limit }\end{array}$ & $\begin{array}{c}\text { Upper } \\
\text { limit }\end{array}$ & Z-Value & $\mathrm{p}$-Value \\
\hline Jin_1, 2011 & Con tusion & -0.610 & 0.470 & 0.221 & -1.532 & 0311 & -1.299 & 0.194 \\
\hline Jin_2, 2011 & Contusion & -0.476 & 0.523 & 0.274 & -1.501 & 0.550 & -0.909 & 0.363 \\
\hline Mitsui, 2003 & Contusion & -2.772 & 0.814 & 0.663 & -4.368 & -1.176 & -3.404 & 0.001 \\
\hline Mitsui, 2005 & Contusion & -1.171 & 0.513 & 0.263 & -2.177 & -0.166 & -2.284 & 0.022 \\
\hline Mitsui_1, 2011 & Con tusion & -1.161 & 0.525 & 0.276 & $-2,190$ & -0.132 & -2.211 & 0.027 \\
\hline Mitsui_2, 2011 & Contusion & -1.490 & 0.519 & 0.270 & -2.507 & -0.472 & -2.869 & 0.004 \\
\hline Neuhuber_1, 2008 & Contusion & -1.239 & 0.488 & 0.238 & -2.196 & -0.282 & -2.537 & 0.011 \\
\hline \multirow[t]{2}{*}{ Neuh uber_2, 2008} & Con tusion & -0.392 & 0.451 & 0.204 & -1.277 & 0.493 & -0.868 & 0.385 \\
\hline & Con tusion & -1.002 & 0.183 & 0.033 & -1.360 & -0.644 & -5.482 & 0.000 \\
\hline Temeltas_1, 2009 & Transection & -2.607 & 0.726 & 0.527 & -4.029 & -1.185 & -3.593 & 0.000 \\
\hline \multirow[t]{3}{*}{ Temeltas_2,2009 } & Transection & -1.033 & 0.591 & 0349 & -2.191 & 0.125 & -1.748 & 0.080 \\
\hline & Transection & -1.661 & 0.458 & 0.210 & -2.559 & -0.763 & -3.624 & 0.000 \\
\hline & Overall & -1.093 & 0.170 & 0.029 & -1.425 & -0.760 & -6.435 & 0.000 \\
\hline
\end{tabular}

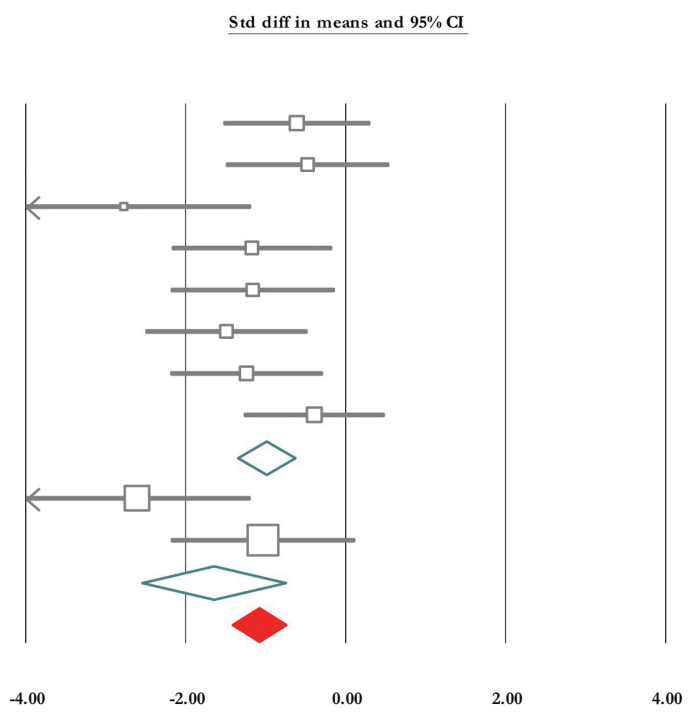

Fig. 3. Micturition pressure improvement based on spinal cord injury type. CI, confidence interval.

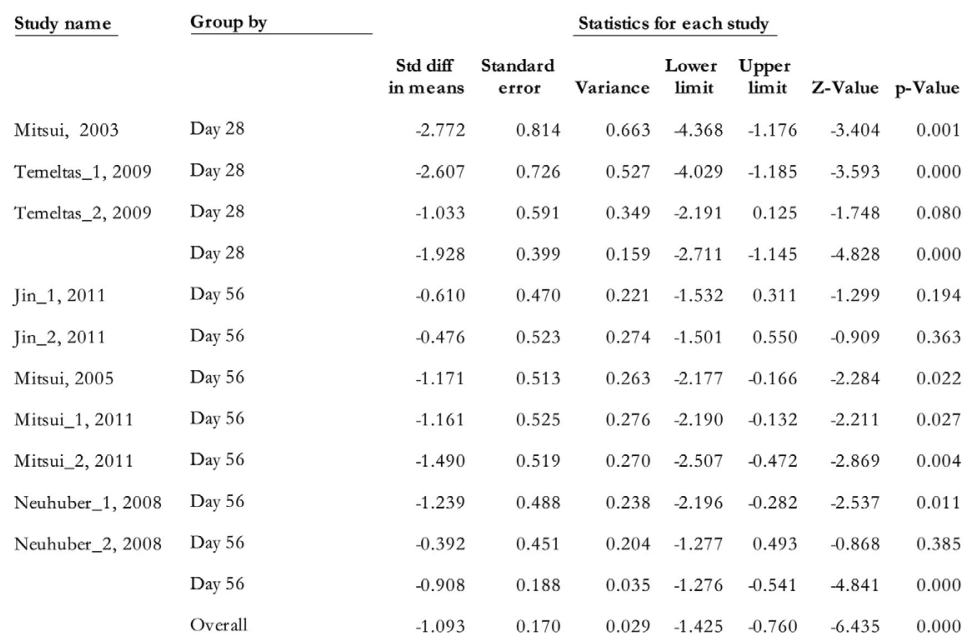

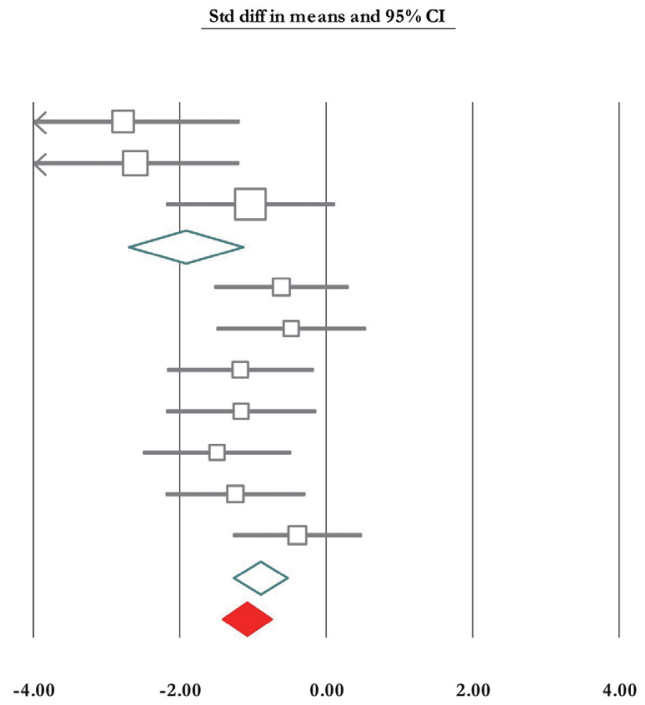

Fig. 4. Micturition pressure improvement based on the time of urodynamics assessment. CI, confidence interval.

(Fig. 3). In the second subgroup study, the results of urodynamic showed that SMD change of micturition pressure 28 days posttransplantation reached $-1.93(95 \% \mathrm{CI},-2.71$ to -1.15$)$ $(\mathrm{P}<0.001)$ and it was $-0.91(95 \% \mathrm{CI},-1.28$ to -0.54$)(\mathrm{P}<0.001)$ on day 56 (Fig. 4).

\section{Residual Urine Volume}

Of 10 trials, 6 experiments $(n=155 ; 87$ treatments and 68 nontreated controls) demonstrated data related to RV [28-33]. The SMD change of residual urine volume from basal levels based on fixed model analysis was -0.47 (95\% CI, -0.81 to -0.14 ) $(\mathrm{P}=0.005)$ (Fig. 5). Heterogeneity assay revealed $\mathrm{P}<0.001$ and Higgin's' $I^{2}$ was $81.72 \%$. However, after subgroup analysis based on SCI type, it decreased to $47.89 \%$ in contusion and $46.31 \%$ in transection model. Also, mixed model subgroup analysis results showed that in contusion model, the SMD was -0.27 (95\% CI, -0.74 , to 0.2$)(\mathrm{P}=0.266)$ while it was -4.78 in transaction model (95\% CI, -6.81 to -2.76$)(\mathrm{P}<0.001)($ Fig. 5). Also, we performed a subgroup analysis based on urodynamic date post-cell transplantation. Twenty-eight days after treatment, SMD was -3.69 


\begin{tabular}{|c|c|c|c|c|c|c|c|c|}
\hline \multirow[t]{2}{*}{ Study name } & \multirow[t]{2}{*}{ Group by } & \multicolumn{7}{|c|}{ Statistics for each study } \\
\hline & & $\begin{array}{l}\text { Std diff } \\
\text { in means }\end{array}$ & $\begin{array}{c}\text { Standard } \\
\text { error }\end{array}$ & Variance & $\begin{array}{r}\text { Lower } \\
\text { limit }\end{array}$ & $\begin{array}{c}\text { Upper } \\
\text { limit }\end{array}$ & Z-Value & $\mathrm{p}$-Value \\
\hline Jin_1, 2011 & Contusion & 0.927 & 0.483 & 0.234 & -0.020 & 1.875 & 1.918 & 0.055 \\
\hline Jin_2, 2011 & Con tusion & 0.077 & 0.517 & 0.267 & -0.936 & 1.089 & 0.148 & 0.882 \\
\hline Mitsui, 2003 & Con tusion & -1.691 & 0.680 & 0.462 & -3.024 & -0.359 & -2.488 & 0.013 \\
\hline Mitsui, 2005 & Con tusion & -0.544 & 0.483 & 0.233 & -1.490 & 0.403 & -1.126 & 0.260 \\
\hline Mitsui_1, 2011 & Con tusion & -0.115 & 0.486 & 0.236 & -1.068 & 0.838 & -0.236 & 0.813 \\
\hline Mitsui_2, 2011 & Con tusion & -0.665 & 0.472 & 0.223 & -1.591 & 0.260 & -1.410 & 0.159 \\
\hline Neuh uber_1, 2008 & Con tusion & -0.675 & 0.460 & 0.211 & -1.576 & 0.226 & -1.468 & 0.142 \\
\hline \multirow[t]{2}{*}{ Neuh uber_2, 2008} & Con tusion & 0.076 & 0.447 & 0.200 & -0.801 & 0.953 & 0.170 & 0.865 \\
\hline & Con tusion & -0.271 & 0.243 & 0.059 & -0.747 & 0.206 & -1.113 & 0.266 \\
\hline Temeltas_1, 2009 & Transection & -5.987 & 1.223 & 1.495 & -8.384 & -3.591 & -4.897 & 0.000 \\
\hline \multirow[t]{3}{*}{ Temeltas_2, 2009} & Transection & -3.896 & 0.924 & 0.853 & -5.706 & -2.086 & -4.218 & 0.000 \\
\hline & Transection & -4.788 & 1.034 & 1.070 & -6.816 & -2.761 & -4.629 & 0.000 \\
\hline & Overall & -0.507 & 0.237 & 0.056 & -0.971 & -0.043 & -2.143 & 0.032 \\
\hline
\end{tabular}

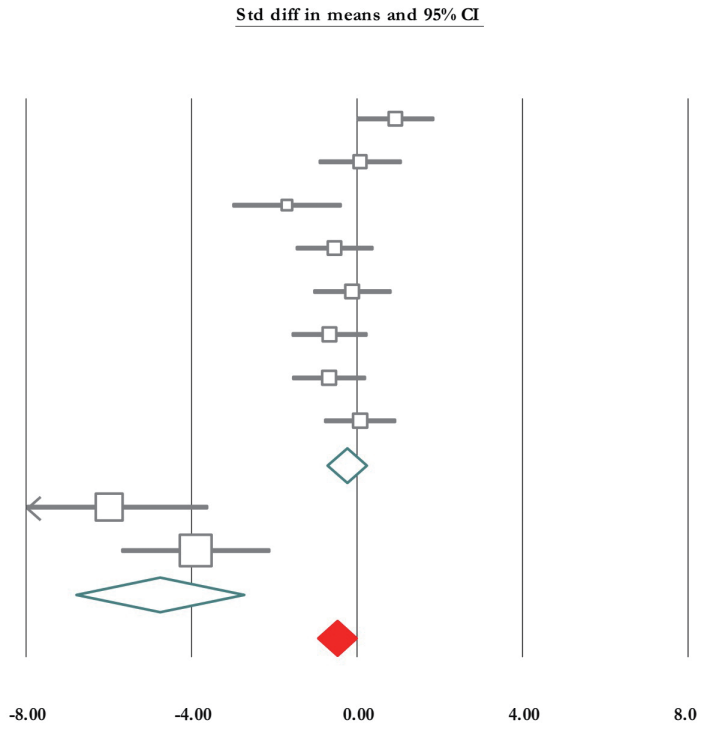

Fig. 5. Residual urine volume improvement based on spinal cord injury type. CI, confidence interval.

\begin{tabular}{|c|c|c|c|c|c|c|c|c|}
\hline Study name & Group by & & & Statistics & for each & study & & \\
\hline & & $\begin{array}{c}\text { Std diff } \\
\text { in means }\end{array}$ & $\begin{array}{c}\text { Standard } \\
\text { error }\end{array}$ & Variance & $\begin{array}{c}\text { Lower } \\
\text { limit }\end{array}$ & $\begin{array}{c}\text { Upper } \\
\text { limit }\end{array}$ & Z-Value & p-Value \\
\hline Mitsui, 2003 & Day 28 & -1.691 & 0.680 & 0.462 & -3.024 & -0.359 & -2.488 & 0.013 \\
\hline Temeltas_1, 2009 & Day 28 & -5.987 & 1.223 & 1.495 & -8.384 & -3.591 & -4.897 & 0.000 \\
\hline Temeltas_2, 2009 & Day 28 & -3.896 & 0.924 & 0.853 & -5.706 & -2.086 & -4.218 & 0.000 \\
\hline & Day 28 & -3.698 & 1.226 & 1.504 & -6.102 & -1.295 & -3.016 & 0.003 \\
\hline Jin_1, 2011 & Day 56 & 0.927 & 0.483 & 0.234 & -0.020 & 1.875 & 1.918 & 0.055 \\
\hline Jin_2, 2011 & Day 56 & 0.077 & 0.517 & 0.267 & -0.936 & 1.089 & 0.148 & 0.882 \\
\hline Mitsui, 2005 & Day 56 & -0.544 & 0.483 & 0.233 & -1.490 & 0.403 & -1.126 & 0.260 \\
\hline Mitsui_1, 2011 & Day 56 & -0.115 & 0.486 & 0.236 & -1.068 & 0.838 & -0.236 & 0.813 \\
\hline Mitsui_2, 2011 & Day 56 & -0.665 & 0.472 & 0.223 & -1.591 & 0.260 & -1.410 & 0.159 \\
\hline Neuhuber_1, 2008 & Day 56 & -0.675 & 0.460 & 0.211 & -1.576 & 0.226 & -1.468 & 0.142 \\
\hline Neuhuber_2, 2008 & Day 56 & 0.076 & 0.447 & 0.200 & -0.801 & 0.953 & 0.170 & 0.865 \\
\hline & Day 56 & -0.139 & 0.216 & 0.047 & -0.562 & 0.284 & -0.644 & 0.520 \\
\hline & Overall & -0.246 & 0.213 & 0.045 & -0.662 & 0.171 & -1.156 & 0.247 \\
\hline
\end{tabular}

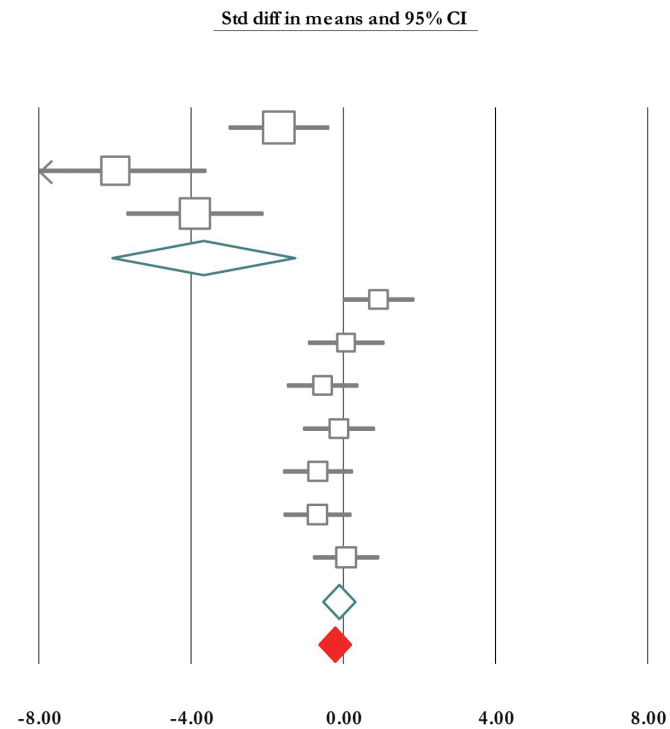

Fig. 6. Residual urine volume improvement based on the time of urodynamics assessment. CI, confidence interval.

(95\% CI, -6.10 to -1.29$)(\mathrm{P}=0.003)$ and in 56 days post-cell transplantation was $-0.13(95 \% \mathrm{CI},-0.56$ to 0.28$)(\mathrm{P}=0.52)$ (Fig. 6). Heterogeneity did not differ in subgroup analysis in 28 days after cell transplantation but it was reduced after 8 weeks postcell transplantation (Higgins' $\mathrm{I}^{2}=30.05 \%, \mathrm{P}=0.199$ ).

\section{Nonvoiding Contraction}

Of 9 trials, 5 experiments $(n=143 ; 80$ treatments and 63 controls) released data on nonvoiding contraction [28-30,32,33].
The SMD change of nonvoiding contraction alleviation was $-0.942(95 \%$ CI, -1.281 to -0.602$)(\mathrm{P}<0.001)$. Heterogeneity analysis indicated $\mathrm{P}=0.138$ and Higgins' $\mathrm{I}^{2}$ was $35.03 \%$. Subgroup analysis results showed that in contusion model and 56 days after cell implantation, SMD was - 1.023 (95\% CI, -1.40 to $-0.65)(\mathrm{P}<0.001)$ and in transaction model and 28 days after treatment it was -0.591 (95\% CI, -1.37 to 0.19) $(\mathrm{P}=0.139)$ (Fig. 7). 


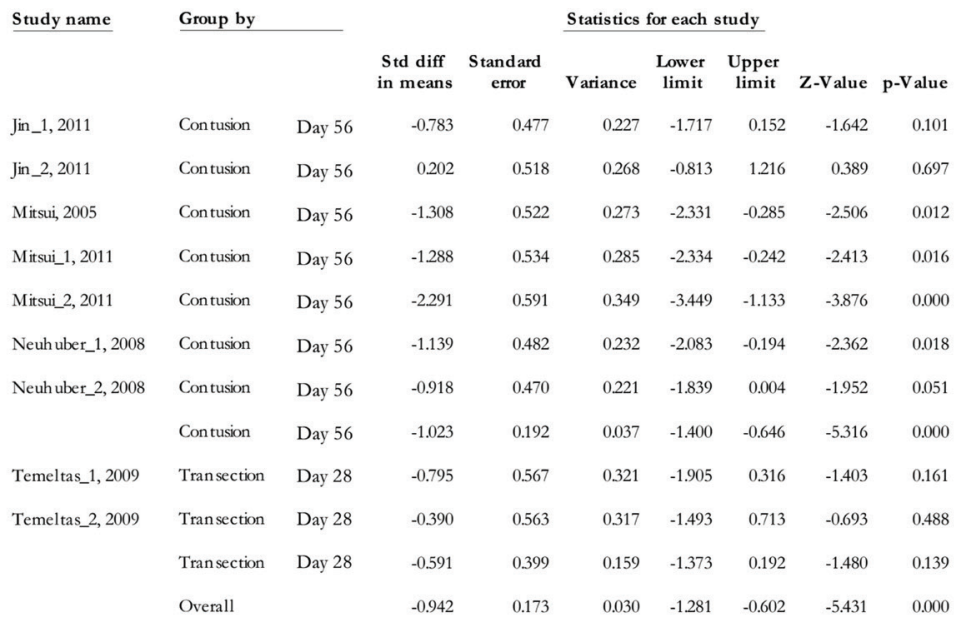

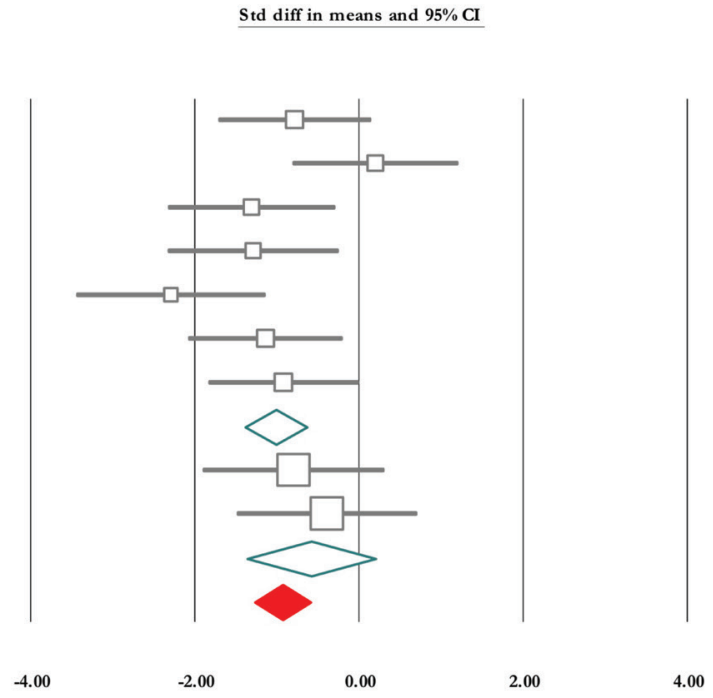

Fig. 7. Nonvoiding contraction improvement based on spinal cord injury type and the time of urodynamics assessment. CI, confidence interval.

\begin{tabular}{|c|c|c|c|c|c|c|}
\hline \multirow[t]{2}{*}{ Study name } & \multirow[t]{2}{*}{ Group by } & \multicolumn{5}{|c|}{ Statistics for each study } \\
\hline & & $\begin{array}{c}\text { Std diff } \\
\text { in means }\end{array}$ & $\begin{array}{c}\text { Lower } \\
\text { limit }\end{array}$ & $\begin{array}{c}\text { Upper } \\
\text { limit }\end{array}$ & Z-Value & p-Value \\
\hline Jin_1, 2011 & Contusion & 0.876 & -0.067 & 1.818 & 1.821 & 0.069 \\
\hline Jin_2, 2011 & Contusion & -0.137 & -1.150 & 0.876 & -0.265 & 0.791 \\
\hline Mitsui, 2005 & Contusion & -0.236 & -1.169 & 0.697 & -0.496 & 0.620 \\
\hline Neuhuber_1, 2008 & Contusion & 0.052 & -0.825 & 0.928 & 0.116 & 0.908 \\
\hline Neuhuber_2, 2008 & Contusion & -1.749 & -2.779 & -0.718 & -3.326 & 0.001 \\
\hline Mitsui_1, 2011 & Contusion & -0.028 & -0.981 & 0.924 & -0.058 & 0.954 \\
\hline Mitsui_2, 2011 & Contusion & -1.603 & -2.638 & -0.568 & -3.036 & 0.002 \\
\hline Park_1, 2010 & Contusion & -0.047 & -1.035 & 0.940 & -0.094 & 0.925 \\
\hline \multirow[t]{2}{*}{ Park_2, 2010} & Contusion & -0.229 & -1.323 & 0.865 & -0.410 & 0.681 \\
\hline & Contusion & -0.326 & -0.856 & 0.204 & -1.205 & 0.228 \\
\hline Temeltas_1, 2009 & Transection & -1.698 & -2.932 & -0.465 & -2.698 & 0.007 \\
\hline \multirow[t]{3}{*}{ Temeltas_2, 2009} & Transection & -1.438 & -2.654 & -0.222 & -2.317 & 0.020 \\
\hline & Transection & -1.566 & -2.432 & -0.700 & -3.544 & 0.000 \\
\hline & Overall & -0.664 & -1.115 & -0.212 & -2.878 & 0.004 \\
\hline
\end{tabular}

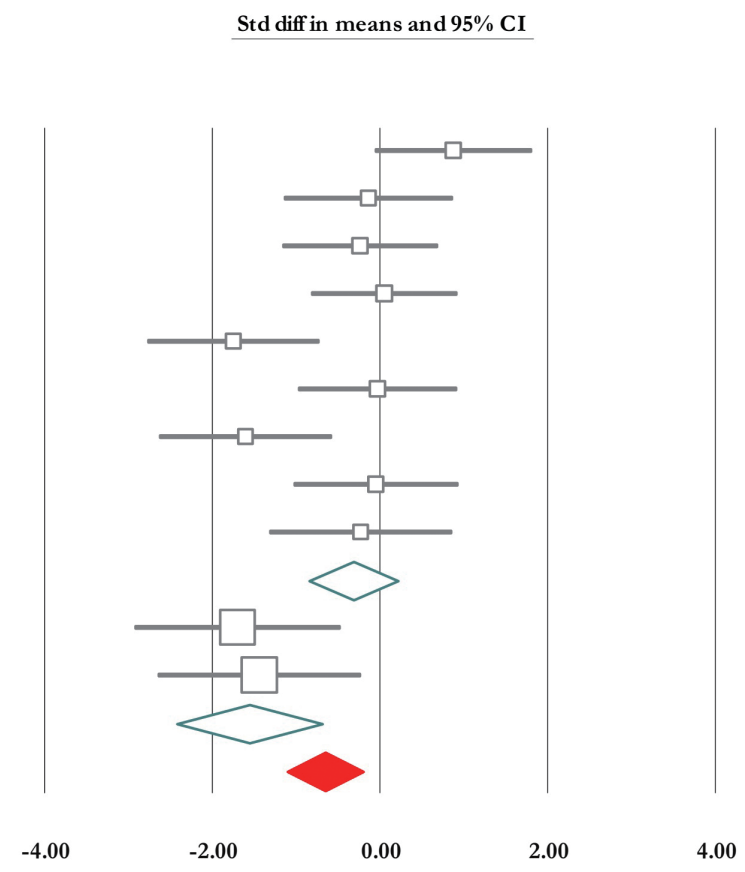

Fig. 8. Bladder capacity improvement based on spinal cord injury type. CI, confidence interval.

\section{Bladder Capacity}

Of 11 trials, 6 experiments $(\mathrm{n}=185$; 93 treatments and 92 controls) released data related to bladder capacity $[19,28-30,32,33]$. Overall SMD based on fixed model analysis was -0.453 (95\% CI, -0.758 to -0.147$)(\mathrm{P}=0.004)$. Heterogeneity analysis revealed $\mathrm{P}=0.002$ and Higgins' $\mathrm{I}^{2}$ was $64.67 \%$. The SMD change of bladder capacity based on mixed model analysis in contusion and transaction model was $-0.32(95 \% \mathrm{CI},-0.85$ to 0.2$)$ $(\mathrm{P}=0.228)$, and -1.566 (95\% CI, -2.43 to -0.70$)(\mathrm{P}<0.001)$ (Fig. 8). Also, it was -0.906 (95\% CI, -1.56 to -0.26$)(\mathrm{P}=0.006)$, and $-0.325(95 \% \mathrm{CI},-0.67$ to 0.021$)(\mathrm{P}=0.065)$ at 28 and 56 days after transplantation (Fig. 9). Heterogeneity did not decrease in 


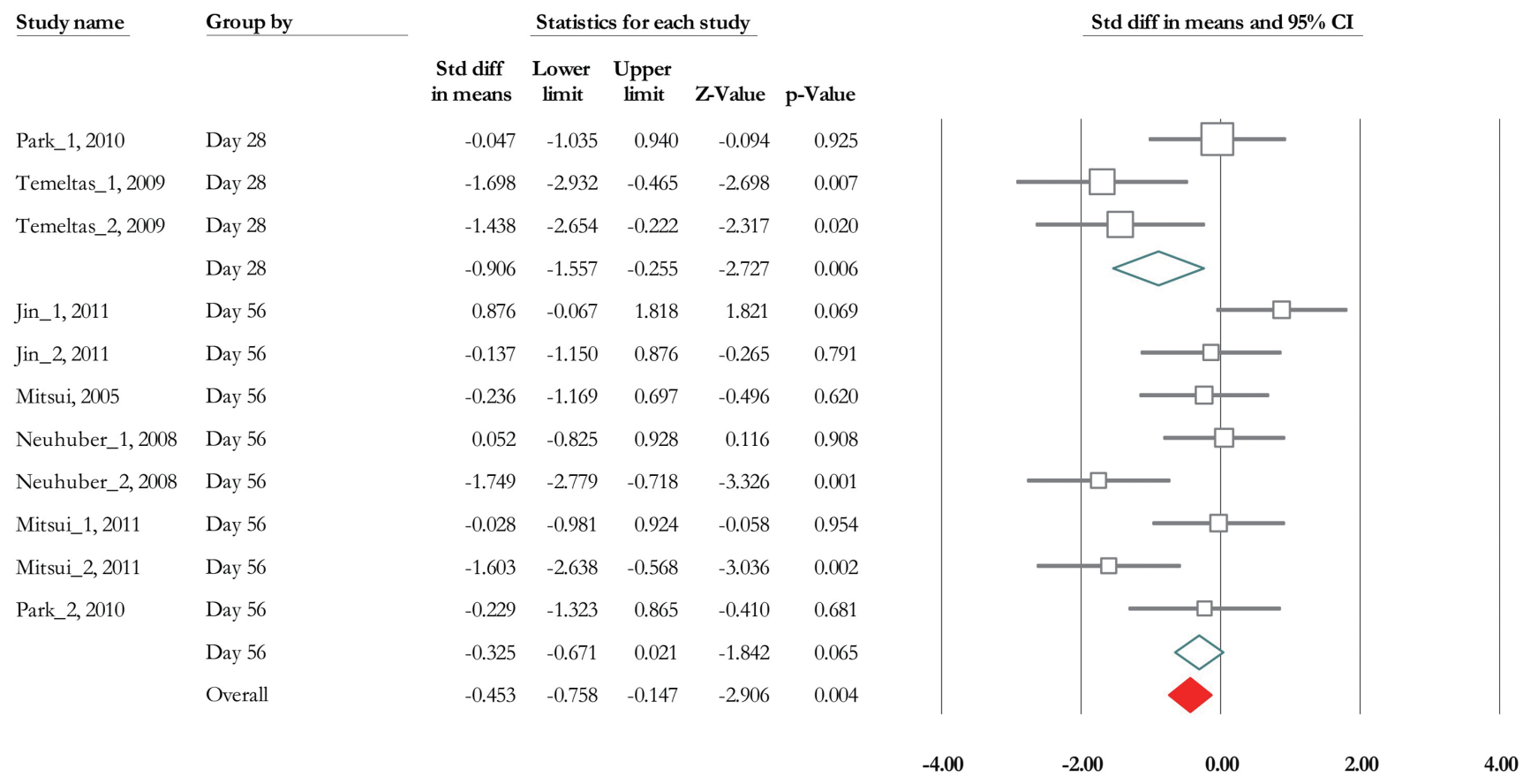

Fig. 9. Bladder capacity improvement based on the time of urodynamics assessment. CI, confidence interval.

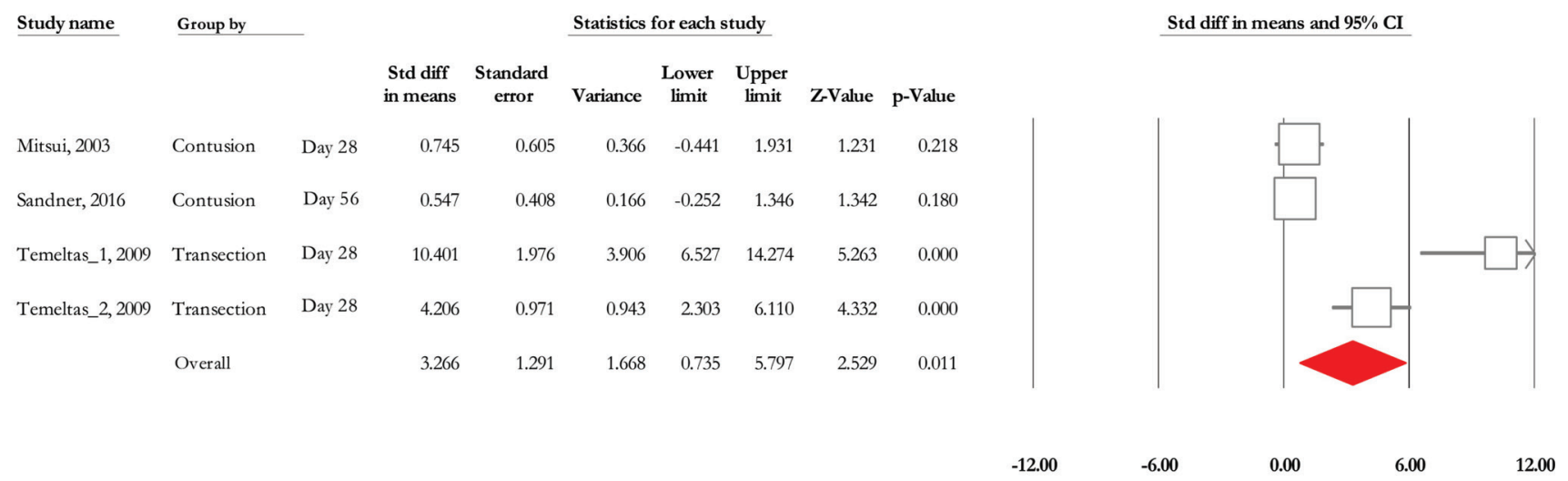

Fig. 10. Micturition volume improvement based on spinal cord injury type and the time of urodynamics assessment. CI, confidence interval.

subgroup analysis based on urodynamics date, however in transection model Higgins' $\mathrm{I}^{2}$ was $0 \%(\mathrm{P}=0.768)$.

\section{Micturition Volume}

Of 4 trials, three experiments $(\mathrm{n}=66 ; 38$ treatments and 28 controls) released data on micturition volume $[29,31,34]$. According to the mixed model analysis, the SMD change of micturition volume reached 1.23 (95\% CI, 0.619 to 1.855$)(\mathrm{P}<$ 0.001 ) (Fig. 10). Heterogeneity analysis revealed $\mathrm{P}<0.001$ and
Higgins' $I^{2}$ was $91.27 \%$. Due to the limited number of experiments related to micturition volume, we could not conduct subgroup analysis.

\section{Publication Bias}

We summarized 10 studies based on the Funnel plot analysis (Fig. 11). According to the Begg and Mazumdar's correlation, we found no publication bias in the meta-analysis. 


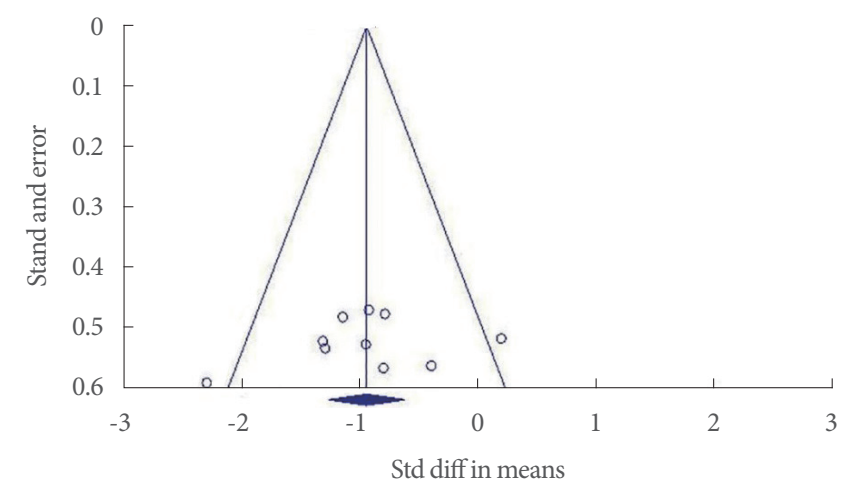

Fig. 11. Funnel plot of standard error by the standard difference in means.

\section{DISCUSSION}

Laboratory animals are widely used to evaluate the medication's efficacy and toxicity. The biological similarity to humans is one of the most important characteristics of laboratory animals such as mice and rats [35]. Thus, in most experimental NGB studies, these animals are preferred. The regulation of micturition requires connections between the brain and extensive tracts in the spinal cord that involve sympathetic, parasympathetic, and somatic systems. Damage of the cerebral cortex, brain stem, basal ganglia, and spinal cord following neurological disorders lead to NGB [36-40]. Generally, upper motor neuron lesions (above the sacral cord) can lead to neurogenic detrusor overactivity and underactive or acontractile detrusor could be evident after lower motor neuron injuries such as the lower lumbar cord, conus or cauda equina lesions and peripheral neuropathies [41,42].

\section{NGB Following Stroke}

MCAO to induce an acute ischemic model [43] and common carotid occlusion induced ischemia are 2 common animal models that lead to bladder overactivity. The variety of receptors including dopamine, glutamate, and gamma-aminobutyric acid (GABA) receptors are involved in the pathogenesis of these models [44-46]. It has been shown that reduction of nerve growth factor, as well as increment of muscarinic receptors in central and peripheral nervous systems, play a role in the regulation of the micturition reflex $[43,44,47]$. Nerve growth factor mediates morphological and functional changes in sensory neurons innervating the bladder [47], and muscarinic receptors contribute to control of the micturition reflex [46]. Following a hemispheric stroke, urinary complaints such as nocturnal uri- nary frequency, urinary incontinence, difficulty in voiding, and urinary retention are common. Also, NGB may lead to a considerable alteration in cystometric parameters. For example, in the hemispheric stroke, urodynamic study results show detrusor overactivity, a condition is related to uncontrolled relaxation sphincter and nonrelaxing urethra [48] and in cerebral hemorrhage moreover, the detrusor overactivity, low-compliance bladder, acontractile detrusor and detrusor-sphincter dyssynergia is seen [49].

\section{NGB Following PD}

Bladder dysfunction is a common nonmotor complication in PD. The brain pathology causing the bladder dysfunction involves an altered dopamine in basal ganglia-frontal circuit, which suppresses the micturition reflex [50]. This reflex is under control of dopamine [51] (D1: inhibitory and D2: facilitatory) and GABA (inhibitory).

The loss of dopaminergic neurons in the substantia nigra, which is usually achieved by injecting 6-hydroxydopamine in medial forebrain of rats for modeling of PD [52], is associated with reduction of striatal dopamine levels. This causes a reduction of the D1 output and leading to detrusor overactivity [53]. The most common urodynamic study finding in $\mathrm{PD}$ is detrusor overactivity $[54,55]$.

\section{NGB Following MS}

EAE is the most common animal model in a rodent for the induction of MS-like pathology. Demyelination in this model is associated with the infiltration of T cells, macrophages, and $\mathrm{B}$ cells [56]. Active induction by immunization with myelin antigens and passive induction by the adoptive transfer of preactivated myelin-specific $\mathrm{T}$ cells into naïve mice are 2 main methods of EAE induction in the mice [57,58]. Myelin oligodendrocyte glycoprotein peptide (MOG35-55), which induces relapsing-remitting EAE in C57BL6 mice has been confirmed to be a useful model to investigate the mechanisms of NGB [59]. Urodynamic findings of the EAE model are included detrusor-external sphincter dyssynergia, detrusor overactivity, and detrusor hypocontractility $[60,61]$.

\section{NGB Following SCI}

Several SCI induction models are reported in the literature [62]. Spinal cord transection and contusion models are frequently used methods for the induction of NGB [63].

SCI causes severe deficits in the urinary system besides of 
sensory and motor loss [37]. Urinary dysfunction is the result of supraspinal input, afferent input to the spinal cord disruption, and reorganization of intraspinal circuitry in response to injury [38]. Detrusor-sphincter dyssynergia, hyperreflexia, and autonomic dysreflexia are the result of this disruption, too [39]. Additionally, significant structural, physiological, and molecular alterations occur in the bladder in SCI conditions [40]. In spinal shock phase of SCI, the bladder is acontractile. Although catheterization controls this disruption in human, it decreases the quality of life and increases the rate of urinary tract infection. Tissue destruction of the pontine micturition centers located at the sacral cord shows the synergy removal between the detrusor and sphincter, contributing to detrusor-sphincter dyssynergia $[64,65]$. Complete deterioration of bladder compliance, function, infection, and other lower urinary tract complications are the other consequences of SCI [66] and also increment of bladder wall thickness as a result of larger collagen percentage is a common sequel of NGB induced by SCI [67]. Considering the underlying recovery mechanism, it was revealed, the type $\mathrm{C}$ fibers are the major afferents in a spinal segmental reflex [41]. In the case of NGB dysfunction, the sensitization of C-fiber afferent bladder, and destroying of GABAergic input to preganglionic neurons of parasympathetic lead to nonvoiding contraction in the bladder detrusor muscles [68]. Following SCI, disruption of neuron entry from supraspinal micturition center impairs the coordination among the detrusor and external urethral sphincter [69].

SCs transplantation in the management of neuro-urological diseases is accompanied with promising outcomes. However, its application is limited in the clinic. Three major types of SCs e.g. adult SC or tissue-specific SC, embryonic stem cells, and induced pluripotent stem cells [70] are more frequently used cells in the experimental and clinical researches. The ability of myelin regeneration and axonal growth promotion and, differentiation of SCs into neuronal or glial cells are the major reasons for selection the specific type of SCs. Despite the limitations and difficulties, conducting researches on the recovery of bladder is a promising approach in the field of neuro-urology. In the studies included in this review, the frequently used cells were bone BMSc, hAFSC, hUCMSC, and NPCs. The viability of NRP/GRP cells in the injured spinal cord and the ability of migration, differentiation and neuronal development of these cells are reported in the previous studies [71]. Also, different studies reported that development in the recovery of the bladder function was achieved by transplantation of NPC [29,
$33,72]$. SCs are biologically self-renewing adult cells with the potency of differentiation to many types of cells even different tissues. Also, these cells can be used in the recovery of the damaged bladder by differentiation into smooth muscle cells of the bladder [73,74]. Mechanisms of SCs involved in the recovery of bladder dysfunction are include migration, differentiation, and paracrine effects [73] or in PD model, neurons with tyrosine hydroxylase activity in the treated substantia nigra pars compacta, suggesting that functional improvement requires a juxtacrine effect [23].

However, there are some concerns about the use of NPCs including the lack of inefficient tracking systems, moderate cell survival [18,75], and glial scar formation [76]. Among the enrolled studies, most cells used in the SCI model were NPCs. Irrespective of its cause, after SCI, disruption of neural circuits influences excitatory and inhibitory inputs and result in failure of special cellular functions in neurons [77]. The ability of NPCs in neuronal regeneration following direct transplantation into the injured site is the main reason for using these cells. The other frequently used cell was MSCs that are examined in clinical trials too [78-81]. Its safety is approved [82] and the ability of transdifferentiation into neurons and glial cells is shown $[83,84]$. Previously, a meta-analysis study evaluated the bladder recovery by SC therapy in SCI-induced bladder dysfunction with controlling the SCI model to reduce heterogeneities [18]. In our systematic review and meta-analysis, in addition to the controlling SCI model (transaction or contusion), the timing of the urodynamic assessment (28 days or 8 weeks post-cell transplantation) also was evaluated as a possible source of heterogeneity. The other important factors that may be influenced on the outcome of the study were the used cell type, the route, and timing of cell transplantation. In the majority of the included studies in the meta-analysis, the rout of transplantation was direct injection into the lesion site or intrathecal. We did not include the other rout of transplantation in our analysis. Also, the timing of cell transplantation was similar and 9-day postinjury. Therefore, we did not perform the subgroup analysis for these issues. The other important factor was the rout of transplantation. The main rout in SCI model was intrathecal and the other less common methods were an intrabladder wall and/or intravenous. Hence, due to this heterogeneity, we only included only intrathecal administration in our meta-analysis. The cell type did not consider as a heterogeneous factor, due to the cells entity was the same and they possess neuro-regeneration capacity. Moreover, we enrolled the other neurological diseases that may 
be a cause of NGB.

In conclusion, the present systematic review and meta-analysis regarding bladder recovery after SC therapy in SCI demonstrate significant improvements of pressure after SC transplantation in both contusion and transaction models in 2-time points i.e., 4 and 8 weeks. Residual urine volume, micturition volume, and bladder capacity improved after treatment only in the 28 days after transplantation in the transaction model of SCI. Nonvoiding contraction recovered only in 56 days posttransplantation in the contusion model. Considering the application of SC in SCI preclinical studies, high-quality experiments to reduce the potential risk of bias are necessary for improved understanding of bladder recovery. Also due to limited studies on the relation of other neurological disorders such as PD, stroke, and MS with NGB, additional studies with the modified methodology to reduce the risk of bias are needed to prove the underlying mechanism and to achieve an appropriate approach for bladder recovery.

\section{AUTHOR CONTRIBUTION STATEMENT}

- Conceptualization: HSP, SH, RR, JM, NM

- Data curation: HSP, FP, JM, NM

- Formal analysis: SSE

- Funding acquisition: $S H$

- Methodology: SH, FP, SSE

- Project administration HSP, SH

\section{REFERENCES}

1. Wein AJ, Rackley RR. Overactive bladder: a better understanding of pathophysiology, diagnosis and management. J Urol 2006;175:S510.

2. Dorsher PT, McIntosh PM. Neurogenic bladder. Adv Urol 2012; 2012:816274.

3. Anderson KD. Targeting recovery: priorities of the spinal cord-injured population. J Neurotrauma 2004;21:1371-83.

4. Hajebrahimi S, Chapple CR, Pashazadeh F, Salehi-Pourmehr H. Management of neurogenic bladder in patients with Parkinson's disease: a systematic review. Neurourol Urodyn 2019;38:31-62.

5. Hajebrahimi S, Azaripour A, Sadeghi-Bazargani H. Clinical and transperineal ultrasound findings in females with stress urinary incontinence versus normal controls. Pak J Biol Sci 2009;12:1434-7.

6. Wyndaele JJ, Madersbacher H, Kovindha A. Conservative treatment of the neuropathic bladder in spinal cord injured patients.
Spinal Cord 2001;39:294-300.

7. Gajewski JB, Schurch B, Hamid R, Averbeck M, Sakakibara R, Agrò EF, et al. An International Continence Society (ICS) report on the terminology for adult neurogenic lower urinary tract dysfunction (ANLUTD). Neurourol Urodyn 2018;37:1152-61.

8. de Sèze M, Ruffion A, Denys P, Joseph PA, Perrouin-Verbe B; GENULF. The neurogenic bladder in multiple sclerosis: review of the literature and proposal of management guidelines. Mult Scler 2007;13:915-28.

9. Sauerwein D. Die operative Behandlung der spastischen Blasenlähmung bei Querschnittlähmung. Sakrale Deafferentation (SDAF) mit der Implantation eines sakralen Vorderwurzelstimulators (SARS) Surgical treatment of spastic bladder paralysis in paraplegic patients. Sacral deafferentation with implantation of a sacral anterior root stimulator. Urologe A 1990;29:196-203.

10. Jahn P, Beutner K, Langer G. Types of indwelling urinary catheters for long-term bladder drainage in adults. Cochrane Database Syst Rev 2012;10:CD004997.

11. Salehi-Pourmehr H, Rahbarghazi R, Mahmoudi J, Roshangar L, Chapple CR, Hajebrahimi S, et al. Intra-bladder wall transplantation of bone marrow mesenchymal stem cells improved urinary bladder dysfunction following spinal cord injury. Life Sci 2019;221:20-8.

12. Azizi R, Aghebati-Maleki L, Nouri M, Marofi F, Negargar S, Yousefi M. Stem cell therapy in Asherman syndrome and thin endometrium: Stem cell- based therapy. Biomed Pharmacother 2018;102:33343.

13. Negro A, Hilaire CS, Boehm M. Cell-based regenerative therapies: role of major histocompatibility Complex-1 antigen. In: Stem cells and cancer stem cells, volume 3. Dordrecht: Springer; 2012. p. 173-8.

14. Robey TE, Saiget MK, Reinecke H, Murry CE. Systems approaches to preventing transplanted cell death in cardiac repair. J Mol Cell Cardiol 2008;45:567-81.

15. Sadigh-Eteghad S, Majdi A, McCann SK, Mahmoudi J, Vafaee MS, Macleod MR. D-galactose-induced brain ageing model: a systematic review and meta-analysis on cognitive outcomes and oxidative stress indices. PLoS One 2017;12:e0184122.

16. Amariglio N, Hirshberg A, Scheithauer BW, Cohen Y, Loewenthal $\mathrm{R}$, Trakhtenbrot L, et al. Donor-derived brain tumor following neural stem cell transplantation in an ataxia telangiectasia patient. PLoS Med 2009;6:e1000029.

17. Chen W, Huang Q, Ma S, Li M. Progress in dopaminergic cell replacement and regenerative strategies for Parkinson's disease. ACS Chem Neurosci 2019;10:839-51.

18. Kim JH, Shim SR, Doo SW, Yang WJ, Yoo BW, Kim JM, et al. Bladder recovery by stem cell based cell therapy in the bladder dysfunc- 
tion induced by spinal cord injury: systematic review and metaanalysis. PLoS One 2015;10:e0113491.

19. Park WB, Kim SY, Lee SH, Kim HW, Park JS, Hyun JK. The effect of mesenchymal stem cell transplantation on the recovery of bladder and hindlimb function after spinal cord contusion in rats. BMC Neurosci 2010;11:119.

20. Cho YS, Ko IG, Kim SE, Lee SM, Shin MS, Kim CJ, et al. Oral mucosa stem cells alleviates spinal cord injury-induced neurogenic bladder symptoms in rats. J Biomed Sci 2014;21:43.

21. Fandel TM, Trivedi A, Nicholas CR, Zhang H, Chen J, Martinez AF, et al. Transplanted human stem cell-derived interneuron precursors mitigate mouse bladder dysfunction and central neuropathic pain after spinal cord injury. Cell Stem Cell 2016;19:544-57.

22. Jin Y, Bouyer J, Shumsky JS, Haas C, Fischer I. Transplantation of neural progenitor cells in chronic spinal cord injury. Neuroscience 2016;320:69-82.

23. Campeau L, Soler R, Sittadjody S, Pareta R, Nomiya M, Zarifpour $\mathrm{M}$, et al. Effects of allogeneic bone marrow derived mesenchymal stromal cell therapy on voiding function in a rat model of Parkinson disease. J Urol 2014;191:850-9.

24. Soler R, Füllhase C, Hanson A, Campeau L, Santos C, Andersson KE. Stem cell therapy ameliorates bladder dysfunction in an animal model of Parkinson disease. J Urol 2012;187:1491-7.

25. Liang CC, Lee TH, Chang SD. Effect of umbilical cord blood stem cells transplantation on bladder dysfunction induced by cerebral ischemia in rats. Taiwan J Obstet Gynecol 2016;55:672-9.

26. Liang CC, Shaw SW, Huang YH, Lin YH, Lee TH. Bladder transplantation of amniotic fluid stem cell may ameliorate bladder dysfunction after focal cerebral ischemia in rat. Stem Cells Transl Med 2017;6:1227-36.

27. Jin Z, Ding Y, Xue R, Jia Z, Huang Z, Ding Y, et al. Involvement of interstitial cells of Cajal in bladder dysfunction in mice with experimental autoimmune encephalomyelitis. Int Urol Nephrol 2017; 49:1353-9.

28. Neuhuber B, Barshinger AL, Paul C, Shumsky JS, Mitsui T, Fischer I. Stem cell delivery by lumbar puncture as a therapeutic alternative to direct injection into injured spinal cord. J Neurosurg Spine 2008; 9:390-9.

29. Temeltas G, Dagci T, Kurt F, Evren V, Tuglu I. Bladder function recovery in rats with traumatic spinal cord injury after transplantation of neuronal-glial restricted precursors or bone marrow stromal cells. J Urol 2009;181:2774-9.

30. Jin Y, Neuhuber B, Singh A, Bouyer J, Lepore A, Bonner J, et al. Transplantation of human glial restricted progenitors and derived astrocytes into a contusion model of spinal cord injury. J Neu- rotrauma 2011;28:579-94.

31. Mitsui T, Kakizaki H, Tanaka H, Shibata T, Matsuoka I, Koyanagi T. Immortalized neural stem cells transplanted into the injured spinal cord promote recovery of voiding function in the rat. J Urol 2003; 170:1421-5.

32. Mitsui T, Neuhuber B, Fischer I. Acute administration of AMPA/ Kainate blocker combined with delayed transplantation of neural precursors improves lower urinary tract function in spinal injured rats. Brain Res 2011;1418:23-31.

33. Mitsui T, Shumsky JS, Lepore AC, Murray M, Fischer I. Transplantation of neuronal and glial restricted precursors into contused spinal cord improves bladder and motor functions, decreases thermal hypersensitivity, and modifies intraspinal circuitry. J Neurosci 2005; 25:9624-36.

34. Sandner B, Ciatipis M, Motsch M, Soljanik I, Weidner N, Blesch A. Limited functional effects of subacute syngeneic bone marrow stromal cell transplantation after rat spinal cord contusion injury. Cell Transplant 2016;25:125-39.

35. Bugos O, Bhide M, Zilka N. Beyond the rat models of human neurodegenerative disorders. Cell Mol Neurobiol 2009;29:859-69.

36. Wein AJ, Kavoussi LR, Novick AC, Partin AW, Peters CA, editors. Campbell-Walsh urology: expert consult premium edition: enhanced online features and print, 4-volume set. Amsterdam (the Netherlands): Elsevier Health Sciences; 2011.

37. Craggs MD, Balasubramaniam AV, Chung EA, Emmanuel AV. Aberrant reflexes and function of the pelvic organs following spinal cord injury in man. Auton Neurosci 2006;126-127:355-70.

38. Vizzard MA. Alterations in growth-associated protein (GAP-43) expression in lower urinary tract pathways following chronic spinal cord injury. Somatosens Mot Res 1999;16:369-81.

39. Birder LA. Role of the urothelium in urinary bladder dysfunction following spinal cord injury. Prog Brain Res 2006;152:135-46.

40. Apodaca G, Kiss S, Ruiz W, Meyers S, Zeidel M, Birder L. Disruption of bladder epithelium barrier function after spinal cord injury. Am J Physiol Renal Physiol 2003;284:F966-76.

41. Fowler CJ. Neurological disorders of micturition and their treatment. Brain 1999;122:1213-31.

42. Fowler CJ, Griffiths D, de Groat WC. The neural control of micturition. Nat Rev Neurosci 2008;9:453-66.

43. Lee TH, Kato H, Chen ST, Kogure K, Itoyama Y. Expression of nerve growth factor and trkA after transient focal cerebral ischemia in rats. Stroke 1998:1687-96; discussion 1697.

44. Yokoyama O, Ootsuka N, Komatsu K, Kodama K, Yotsuyanagi S, Niikura $\mathrm{S}$, et al. Forebrain muscarinic control of micturition reflex in rats. Neuropharmacology 2001;41:629-38. 
45. Yokoyama O, Yoshiyama M, Namiki M, de Groat WC. Glutamatergic and dopaminergic contributions to rat bladder hyperactivity after cerebral artery occlusion. Am J Physiol 1999;276:R935-42.

46. Yokoyama O, Yoshiyama M, Namiki M, de Groat WC. Role of the forebrain in bladder overactivity following cerebral infarction in the rat. Exp Neurol 2000;163:469-76.

47. Ochodnický P, Cruz CD, Yoshimura N, Michel MC. Nerve growth factor in bladder dysfunction: contributing factor, biomarker, and therapeutic target. Neurourol Urodyn 2011;30:1227-41.

48. Yamanishi T, Sakakibara R, Uchiyama T, Hirata K. Role of urodynamic studies in the diagnosis and treatment of lower urinary tract symptoms. Urol Sci 2011;22:120-8.

49. Sakakibara R, Hattori T, Yasuda K, Yamanishi T. Micturitional disturbance and the pontine tegmental lesion: urodynamic and MRI analyses of vascular cases. J Neurol Sci 1996;141:105-10.

50. Sakakibara R, Tateno F, Kishi M, Tsuyuzaki Y, Uchiyama T, Yamamoto T. Pathophysiology of bladder dysfunction in Parkinson's disease. Neurobiol Dis 2012;46:565-71.

51. Yoshimura N, Mizuta E, Kuno S, Sasa M, Yoshida O. The dopamine D1 receptor agonist SKF 38393 suppresses detrusor hyperreflexia in the monkey with parkinsonism induced by 1-methyl4-phenyl-1,2,3,6-tetrahydropyridine (MPTP). Neuropharmacology 1993;32:315-21.

52. Campeau L, Soler R, Nomiya M, Andersson K. 1070 Rat bone marrow derived mesenchymal stem cell therapy in a Parkinsonian animal model of detrusor overactivity. Eur Urol Suppl 2012;11:e1070.

53. Seki S, Igawa Y, Kaidoh K, Ishizuka O, Nishizawa O, Andersson KE. Role of dopamine D1 and D2 receptors in the micturition reflex in conscious rats. Neurourol Urodyn 2001;20:105-13.

54. Hattori T, Yasuda K, Kita K, Hirayama K. Voiding dysfunction in Parkinson's disease. Jpn J Psychiatry Neurol 1992;46:181-6.

55. Sakakibara R, Tateno F, Yamamoto T, Uchiyama T. Bowel and bladder disorders in Parkinson's disease. Nihon Rinsho 2017;75:111-8.

56. Traugott U, Stone SH, Raine CS. Chronic relapsing experimental allergic encephalomyelitis. Correlation of circulating lymphocyte fluctuations with disease activity in suppressed and unsuppressed animals. J Neurol Sci 1979;41:17-29.

57. McCarthy DP, Richards MH, Miller SD. Mouse models of multiple sclerosis: experimental autoimmune encephalomyelitis and Theiler's virus-induced demyelinating disease. Methods Mol Biol 2012; 900:381-401.

58. Terry RL, Ifergan I, Miller SD. Experimental autoimmune encephalomyelitis in mice. Methods Mol Biol 2016;1304:145-60.

59. Negoro H, Lutz SE, Liou LS, Kanematsu A, Ogawa O, Scemes E, et al. Pannexin 1 involvement in bladder dysfunction in a multiple sclerosis model. Sci Rep 2013;3:2152.

60. Oppenheimer DR. The cervical cord in multiple sclerosis. Neuropathol Appl Neurobiol 1978;4:151-62.

61. Corcos J. A urological challenge: voiding dysfunction in multiple sclerosis. Can Urol Assoc J 2013;7:S181-2.

62. Yoo KH, Lee SJ. Experimental animal models of neurogenic bladder dysfunction. Int Neurourol J 2010;14:1-6.

63. Abolhasanpour N, Hajebrahimi S, Ebrahimi-Kalan A, Mehdipour A, Salehi-Pourmehr H. Urodynamic parameters in spinal cord injury-induced neurogenic bladder rats after stem cell transplantation: a narrative review. Iran J Med Sci 2020;45:2-15.

64. Yamanishi T, Yasuda K, Sakakibara R, Hattori T, Tojo M, Ito H. The nature of detrusor bladder neck dyssynergia in non-neurogenic bladder dysfunction. J Auton Nerv Syst 1997;66:163-8.

65. Blaivas JG, Sinha HP, Zayed AA, Labib KB. Detrusor-external sphincter dyssynergia: a detailed electromyographic study. J Urol 1981;125:545-8.

66. Yoshiyama M, Nezu FM, Yokoyama O, de Groat WC, Chancellor $\mathrm{MB}$. Changes in micturition after spinal cord injury in conscious rats. Urology 1999;54:929-33.

67. Nagatomi J, Gloeckner DC, Chancellor MB, DeGroat WC, Sacks MS. Changes in the biaxial viscoelastic response of the urinary bladder following spinal cord injury. Ann Biomed Eng 2004;32:1409-19.

68. de Groat WC, Griffiths D, Yoshimura N. Neural control of the lower urinary tract. Compr Physiol 2015;5:327-96.

69. Panicker JN, Fowler CJ, Kessler TM. Lower urinary tract dysfunction in the neurological patient: clinical assessment and management. Lancet Neurol 2015;14:720-32.

70. Leventhal A, Chen G, Negro A, Boehm M. The benefits and risks of stem cell technology. Oral Dis 2012;18:217-22.

71. Bonner JF, Blesch A, Neuhuber B, Fischer I. Promoting directional axon growth from neural progenitors grafted into the injured spinal cord. J Neurosci Res 2010;88:1182-92.

72. Mitsui T, Fischer I, Shumsky JS, Murray M. Transplants of fibroblasts expressing BDNF and NT-3 promote recovery of bladder and hindlimb function following spinal contusion injury in rats. Exp Neurol 2005;194:410-31.

73. Kim JH, Lee SR, Song YS, Lee HJ. Stem cell therapy in bladder dysfunction: where are we? And where do we have to go? Biomed Res Int 2013;2013:930713.

74. Lee HJ, An J, Doo SW, Kim JH, Choi SS, Lee SR, et al. Improvement in spinal cord injury-induced bladder fibrosis using mesenchymal stem cell transplantation into the bladder wall. Cell Transplant 2015;24:1253-63.

75. Ronaghi M, Erceg S, Moreno-Manzano V, Stojkovic M. Challenges 
of stem cell therapy for spinal cord injury: human embryonic stem cells, endogenous neural stem cells, or induced pluripotent stem cells? Stem Cells 2010;28:93-9.

76. Orlandin JR, Ambrósio CE, Lara VM. Glial scar-modulation as therapeutic tool in spinal cord injury in animal models. Acta Cir Bras 2017;32:168-74.

77. Cruz CD, Cruz F. Spinal cord injury and bladder dysfunction: new ideas about an old problem. ScientificWorldJournal 2011;11:21434.

78. Chhabra HS, Sarda K, Arora M, Sharawat R, Singh V, Nanda A, et al. Autologous bone marrow cell transplantation in acute spinal cord injury--an Indian pilot study. Spinal Cord 2016;54:57-64.

79. Cheng H, Liu X, Hua R, Dai G, Wang X, Gao J, et al. Clinical observation of umbilical cord mesenchymal stem cell transplantation in treatment for sequelae of thoracolumbar spinal cord injury. J Transl Med 2014;12:253.

80. Dai G, Liu X, Zhang Z, Yang Z, Dai Y, Xu R. Transplantation of autologous bone marrow mesenchymal stem cells in the treatment of complete and chronic cervical spinal cord injury. Brain Res 2013; 1533:73-9.

81. El-Kheir WA, Gabr H, Awad MR, Ghannam O, Barakat Y, Farghali $\mathrm{HA}$, et al. Autologous bone marrow-derived cell therapy combined with physical therapy induces functional improvement in chronic spinal cord injury patients. Cell Transplant 2014;23:729-45.

82. Xu P, Yang X. The efficacy and safety of mesenchymal stem cell transplantation for spinal cord injury patients: a meta-analysis and systematic review. Cell Transplant 2019;28:36-46.

83. Alexanian AR. An efficient method for generation of neural-like cells from adult human bone marrow-derived mesenchymal stem cells. Regen Med 2010;5:891-900.

84. Moviglia GA, Fernandez Viña R, Brizuela JA, Saslavsky J, Vrsalovic F, Varela G, et al. Combined protocol of cell therapy for chronic spinal cord injury. Report on the electrical and functional recovery of two patients. Cytotherapy 2006;8:202-9.

85. Hu Y, Liao LM, Ju YH, Fu G, Zhang HY, Wu HX. Intravenously transplanted bone marrow stromal cells promote recovery of lower urinary tract function in rats with complete spinal cord injury. Spinal Cord 2012;50:202-7.

86. Temeltas G, Dagci T, Evren V, Lekili M. Effects of neuronal and glial restricted precursor cells transplantation on erectile function after experimentally induced spinal cord injury. J Sex Med 2009;6: 3265-73.

87. DePaul MA, Palmer M, Lang BT, Cutrone R, Tran AP, Madalena $\mathrm{KM}$, et al. Intravenous multipotent adult progenitor cell treatment decreases inflammation leading to functional recovery following spinal cord injury. Sci Rep 2015;5:16795. 